\title{
PENGARUH MODUL TERHADAP PENINGKATAN PENGETAHUAN, SIKAP DAN PRAKTEK KADER DALAM UPAYA PEMBERIAN ASI EKSKLUSIF
}

\author{
Jumiyati ${ }^{1}$, Nugrahaeni ${ }^{2}$, S.A $^{1}$, Ani Margawati $^{3}$ \\ 1Jurusan Gizi Poltekkes Kemenkes Bengkulu \\ 2FKM Universitas Diponegoro \\ ${ }^{3}$ FKIMIK Pascasarjana Universitas Diponegoro \\ yatijumi70@yahoo.co.id
}

\begin{abstract}
ABSTRAK
Rendahnya cakupan ASI eksklusif dipengaruhi oleh terbatasnya tenaga konselor ASI, belum maksimalnya kegiatan edukasi, sosialisasi dan belum optimalnya membina kelompok pendukung ASI. Kelompok pendukung ASI di masyarakat dapat melibatkan peran kader dengan cara menambah pengetahuan, sikap dan praktek kader. Penelitian bertujuan untuk menganalisis pengaruh modul terhadap peningkatan pengetahuan, sikap dan praktek kader dalam upaya pemberian ASI eksklusif. Desain quasi experimen dengan rancangan non randomized control group pre test - post test design. Sampel penelitian 60 kader (30 kelompok perlakuan dan 30 kontrol). Perilaku kader diukur 4 kali yaitu pada kondisi awal, setelah pelatihan, satu bulan, dan dua bulan setelah pelatihan. Dilakukan uji beda rata-rata. Kelompok perlakuan terjadi peningkatan skor pengetahuan 9,63 poin, post-test bulan pertama 8,94 poin dan post-test bulan kedua 1,55; sikap meningkat 6,35 poin, post tes bulan pertama 7,5 poin dan post-test bulan kedua tidak terjadi peningkatan; praktek meningkat 4,55 poin, post-test bulan pertama 11,8 poin dan post-test bulan kedua 0,39 poin. Kelompok kontrol terjadi peningkatan pengetahuan 3,25 poin, sikap meningkat 2,03 poin dan praktek meningkat 2 poin. Pelatihan dengan menggunakan modul dapat meningkatkan pengetahuan, sikap dan praktek kader dibandingkan kelompok kontrol.
\end{abstract}

Kata kunci: modul pelatihan, pengetahuan, sikap dan praktek kader, ASI eksklusif

\section{ABSTRACT}

\section{THE IMPACT OF MODULE IN IMPROVING KNOWLEDGE, ATTITUDE AND PRACTICE ON THE PROMOTION OF EXCLUSIVE BREASTFEEDING AMONG THE CADRES OF HEALTH}

The low coverage of exclusive breastfeeding was influenced by shortage of breastfeeding counselor, limited educational and socialtization activities, and lack of involvement of breastfeeding support groups. Support groups in the community could involve health service provider participation in improving knowledge, attitude and their practice. The objective of this study was to analyze impact of the module toward the increase of knowledge, attitude and practice of health cadres to promote breastfeeding practices. The design of the study used a quasi experiment with the design of non-randomized control group pre test-post test design. The sample was 60 health cadres (30 as treatment group and 30 as control group). Cadres behavior was measured 4 times on the initial conditions, after training, one month, and two months after training.. The result showed that there was an increased of knowldge in treatment group by 9.63 points, the first month post-test by 8.94 points and at the second post-test by 1.55 , the attitude score increased 6.35 points, the first month post-test by 7,5 points and at the second month test showed no improvement, the practice increased by 4.55 points, the first month post-test by 11.8 points and second month post-test by 0.39 points. In control group, there was an increased of knowledge by 3.25 points, for attitude increased by 2,03 points and practice increased by 2 point. Training using the module could improve knowledge, attitude and practice of health cadres compared to those in the control group.

Keywords: training module, knowledge, attitude and practice of health cadres, exclusive breastfeeding

\section{PENDAHULUAN}

$\mathrm{P}$ emberian ASI sangat penting bagi pertumbuhan dan perkembangan optimal baik fisik maupun mental dan kecerdasan bayi. Oleh karena itu pemberian ASI perlu mendapatkan perhatian ibu dan tenaga kesehatan agar proses menyusui dapat terlaksana dengan baik. ${ }^{1}$ WHO/UNICEF merekomendasikan empat hal penting untuk 
mempertahankan status gizi dan menurunkan penyakit infeksi pada bayi yaitu memberikan ASI kepada bayi segera dalam waktu 30 menit setelah bayi lahir, memberikan hanya ASI saja sejak lahir sampai bayi berusia 6 bulan, memberikan makanan pendamping ASI sejak bayi berusia 6 bulan sampai 24 bulan, dan meneruskan pemberian ASI sampai berusia 24 bulan atau lebih. ${ }^{2}$ Pekan ASI sedunia 2010, United Nations for Children's Emergency Fund (UNICEF) menghimbau semua stakeholder termasuk instansi pemerintah, LSM, profesi kesehatan, institusi akademis, serta para ibu dan masyarakat agar menggerakkan ibu untuk mendapatkan hak mereka terhadap pelayanan kesehatan yang mendukung pemberian Air Susu Ibu (ASI). Sesuai Undang-Undang Kesehatan No. 36 tahun 2009 tentang pemberian ASI eksklusif. ${ }^{3}$

Secara nasional, cakupan pemberian ASI eksklusif di Indonesia berfluktuasi dan menunjukan kecenderungan menurun. Laporan SUSENAS tercatat cakupan pemberian ASI eksklusif pada bayi $0-6$ bulan turun dari $34,3 \%$ (2009) menjadi 33,6\% (2010), demikian juga laporan Riskesdas (2010) menyatukan terjadinya penurunan proporsi pemberian ASI eksklusif 0 - 5 bulan. Pada usia 0 bulan 39,8\% mendapat ASI eksklusif menurun menjadi $32,5 \%$ (usia 1 bulan), 30,7\% (usia 2 bulan), $26,3 \%$ (usia 3 bulan), 25,2\% (usia 4 bulan) dan menjadi $15,3 \%$ pada usia 5 bulan. ${ }^{4}$ Berdasarkan data tersebut menunjukkan bahwa cakupan pemberian ASI eksklusif di Indonesia masih dibawah target $(80 \%)$.

Cakupan pemberian ASI eksklusif di Propinsi Bengkulu juga masih di bawah target nasional. Laporan Dinas Kesehatan Provinsi Bengkulu Tahun 2011, tercatat jumlah bayi yang berumur $0-6$ bulan 34.659 bayi dari 10 kabupaten yang tidak ASI eksklusif 16.650 (48\%) dan ASI eksklusif 16.615(52\%). Sedangkan data profil Dinas Kesehatan Kota Bengkulu jumlah bayi 1.478 yang mendapat ASI eksklusif $46,5 \%$ dan yang tidak ASI eksklusif $53,5 \%$. Dari 20 Puskesmas yang ada di Kota Bengkulu, cakupan pemberian ASI eksklusif di Puskesmas Sukamerindu yaitu $40,3 \%{ }^{5}$

Rendahnya cakupan ASI eksklusif di Indonesia menjadi pemicu ketidak berhasilan program KADARZI. Berbagai penyebabnya antara lain kurangnya pengetahuan ibu akan pentingnya ASI bagi bayi, pemberian makanan yang terlalu dini, meningkatnya promosi susu formula untuk bayi dan kurangnya dukungan dari lingkungan dan praktisi kesehatan. ${ }^{4}$ Walaupun manfaat dan keunggulan ASI sudah banyak diketahui orang, namun praktek menambahan makanan atau minuman selain ASI pada bayi sebelum 6 bulan masih sering terjadi, padahal pemberian makanan selain ASI sebelum 6 bulan menyebabkan gangguan sistim pencernaan karena tidak sesuai dengan kebutuhan gizi, kematangan fisiologis dan daya tahan tubuh bayi, yang berisiko terjadi infeksi (diare), alergi, obesitas dan bahaya lainnya. ${ }^{1}$ Masih sangat terbatasnya tenaga konselor ASI, belum maksimalnya kegiatan edukasi, sosialisasi, advokasi dan kampanye terkait pemberian ASI, masih rendahnya ketersediaan sarana dan prasarana KIE ASI dan belum optimalnya membina kelompok pendukung ASI juga merupakan penyebab rendahnya cakupan ASI Eksklusif. ${ }^{6}$

Kelompok pendukung ASI di masyarakat dapat melibatkan peran kader dengan cara menambah pengetahuan, sikap dan praktek kader dan mengadakan pelatihan menggunakan modul yang sederhana yang sesuai dengan perkembangan keadaan dan kebijakan-kebijakan yang baru. Selama ini kader lebih sering menjadi pelaksana kegiatan saja, belum pernah mendapat pelatihan tentang ASI eksklusif sehingga tidak melakukan pendampingan pemberian ASI. Program pendamping ASI Eksklusif termasuk dalam salah satu indikator keberhasilan Program KADARZI yang seharusnya dilakukan oleh kader pendamping yang sudah terlatih agar kader dapat memotivasi ibu menyusui, biasanya setiap kota atau kabupaten mempunyai kriteria sendiri untuk kader pendampingnya. ${ }^{7}$ Hasil penelitian Sudarmanto, menunjukan terdapat pengaruh pelatihan dengan menggunakan modul pendamping KMS terhadap peningkatan pengetahuan kader dan ketepatan kader dalam interpretasi hasil penimbangan anak di posyandu oleh sebab itu diperlukan upaya pemberdayaan kader. ${ }^{8}$ Demikian juga hasil penelitian di Kota Pasuruan menunjukan bahwa ada pengaruh pendampingan bidan terhadap keberhasilan pemberian ASI eksklusif. ${ }^{9}$

Penelitian ini bertujuan untuk mengembangkan modul dan menganalisis efektifitas modul sebagai upaya peningkatan pengetahuan, sikap dan praktek kader dalam 
pendampingan pemberian ASI eksklusif di Kota Bengkulu.

\section{METODE PENELITIAN}

Desain penelitian menggunakan Quasi experiment dengan rancangan non randomized control group pre-test - post tes design, dilaksanakan bulan Januari-Maret 2013 Intervensi berupa pelatihan menggunakan media modul yang telah dikembangkan dan melalui uji validitas. Pengembangan modul melalui proses identifikasi masalah yang dihadapi kader dan tenaga kesehatan dalam pemberian ASI eksklusif. Uji coba modul pendampingan dilaksanakan dengan cara Focus Group Discussion (FGD) pada kader, tenaga gizi dan dokter di Puskesmas Basuki Rahmat sebanyak 20 kader yang tidak menjadi sampel penelitian.Uji validitas menggunakan korelasi product moment dan pearson. Uji Reliabilitas menggunakan analisa Cronbach's Alpha $>0,60$.

Populasi adalah seluruh kader posyandu yang ada di Puskesmas Sukamerindu dan Puskesmas Sidomulyo Kota Bengkulu berjumlah 105 kader. Sampel sebanyak 30 kelompok intervensi dan 30 kelompok kontrol, dipilih secara purposive sampling. Hasil pre dan post test diukur dengan kuesioner untuk mengukur pengetahuan dan sikap kader, daftar tilik sebagai alat ukur praktek kader dan modul pelatihan sebagai panduan saat menyampaikan materi. Post test dilakukan langsung setelah pelatihan, satu bulan setelah, dan dua bulan setelah pendampingan pada kelompok perlakuan. Analisis bivariat menggunakan uji statistik paired $t$ - test dan independent sample $t$ - test (parametrik) dan uji Wilcoxon Signed Ranks Test dan uji Mann Whitney Test (Non Parametrik).

\section{HASIL}

\section{Karakteristik Kader Pendamping atau Posyandu}

Tabel 1 menunjukkan sebagian besar pada kelompok perlakuan $(56,7 \%)$ dan kelompok kontrol $(63,3 \%)$ berpendidikan SLTA. Disribusi umur pada kelompok perlakuan sebagian besar $(80 \%)$ berumur di atas 35 tahun, sedangkan pada kelompok kontrol sebagian besar $(73,3 \%)$ berumur lebih dari 45 tahun, dan terdapat perbedaan proporsi menurut umur pada kedua kelompok $(p<0,05)$. Berdasarkan lama menjadi kader, pada kelompok perlakuan sebagian besar lebih dari 10 tahun $(60 \%)$, sedangkan pada kelompok kontrol sebagian besar kurang dari 10 tahun (56,7\%). Sumber informasi yang paling sering didengar sebagian besar kelompok perlakukan $(70 \%)$ dan kelompok control $(60 \%)$ menyatakan dari media massa.

Tabel 1

Karakteristik Kader Kelompok Perlakuan dan Kelompok Kontrol

\begin{tabular}{|c|c|c|c|c|c|}
\hline \multirow{2}{*}{$\begin{array}{c}\text { Karakteristik } \\
\text { Kader }\end{array}$} & \multicolumn{2}{|c|}{ Perlakuan } & \multicolumn{2}{|c|}{ Kontrol } & \multirow[b]{2}{*}{$p$} \\
\hline & $n$ & $\%$ & $n$ & $\%$ & \\
\hline \multicolumn{6}{|l|}{ Pendidikan } \\
\hline SMP & 6 & 20,0 & 6 & 20,0 & \multirow{3}{*}{0,801} \\
\hline SLTA & 17 & 56,7 & 19 & 63,3 & \\
\hline PT & 7 & 23,3 & 5 & 16,7 & \\
\hline \multicolumn{6}{|l|}{ Umur } \\
\hline$<35$ Tahun & 6 & 20,0 & 1 & 3,3 & \multirow{3}{*}{0,020} \\
\hline 35 - 45 Tahun & 12 & 40,0 & 7 & 23.3 & \\
\hline$>45$ Tahun & 12 & 40,0 & 22 & 73,3 & \\
\hline \multicolumn{6}{|l|}{ Lama Menjadi Kader } \\
\hline$<10$ Tahun & 12 & 40,0 & 17 & 56,7 & \multirow{3}{*}{0,282} \\
\hline $10-15$ Tahun & 10 & 33,3 & 5 & 16,7 & \\
\hline > 15 Tahun & 8 & 26,7 & 8 & 26,7 & \\
\hline \multicolumn{6}{|l|}{ Sumber Informasi } \\
\hline Media Elektronik & 1 & 3,3 & 1 & 3,3 & \multirow{3}{*}{0,703} \\
\hline Media Massa & 21 & 70,0 & 18 & 60,0 & \\
\hline lain-lain & 8 & 26,7 & 11 & 36,7 & \\
\hline
\end{tabular}


Tabel 2

Tingkat Pengetahuan, Sikap dan Praktek Kader Sebelum Perlakuan

\begin{tabular}{|c|c|c|c|c|c|c|c|}
\hline \multirow{3}{*}{ Perilaku Kader } & \multicolumn{7}{|c|}{ Sebelum Perlakuan } \\
\hline & \multicolumn{3}{|c|}{ Perlakuan $(n=30)$} & \multicolumn{4}{|c|}{ Kontrol $(n=30)$} \\
\hline & Min & $\operatorname{Max}$ & Mean+ SD & Min & Max & Mean+ SD & $p$ \\
\hline Pengetahuan & 58 & 74 & $66,7 \pm 4,08$ & 58 & 76 & $66,7 \pm 5,43$ & $0,107 \mathrm{e}$ \\
\hline Sikap & 55 & 80 & $68,0 \pm 6,92$ & 60 & 75 & $68,3 \pm 4,09$ & $0,839 \mathrm{e}$ \\
\hline \multirow[t]{2}{*}{ Praktek } & 62 & 77 & $67,0+3,56$ & 67 & 75 & $65,7+5,10$ & $0,250^{e}$ \\
\hline & \multicolumn{7}{|c|}{ Sesudah Perlakuan } \\
\hline Pengetahuan & 63 & 88 & $74,6^{a} \pm 6,57$ & 60 & 79 & $69,9^{a} \pm 5,57$ & $0,004 \mathrm{e}$ \\
\hline Sikap & 62 & 82 & $75,0^{b}+5,98$ & 62 & 73 & $70,3^{b}+4,75$ & $0,005^{f}$ \\
\hline Praktek & 65 & 78 & $71,6^{a}+3,56$ & 61 & 68 & $67,4 a+5,09$ & $0,001 \mathrm{e}$ \\
\hline
\end{tabular}

Tabel 3

Perbedaan Skor Pengetahuan, Sikap dan Praktek Sebelum dan Sesudah Pelatihan pada Kelompok Perlakuan dan Kelompok Kontrol

\begin{tabular}{|c|c|c|c|c|c|c|}
\hline \multirow[b]{2}{*}{ Upaya Kader } & \multicolumn{2}{|c|}{ Kelompok Perlakuan $(n=30)$} & \multicolumn{4}{|c|}{ Kelompok Kontrol $(n=30)$} \\
\hline & $\begin{array}{l}\text { Sebelum } \\
\text { perlakuan }\end{array}$ & $\begin{array}{l}\text { Sesudah } \\
\text { perlakuan }\end{array}$ & $p$ & $\begin{array}{l}\text { Sebelum } \\
\text { perlakuan }\end{array}$ & $\begin{array}{l}\text { Sesudah } \\
\text { perlakuan }\end{array}$ & $p$ \\
\hline Pengetahuan & $66,7^{a} \pm 4,08$ & $74,6^{a} \pm 6,57$ & $0,001^{\mathrm{c}}$ & $66,7^{a} \pm 5,43$ & $69,9 a \pm 5,57$ & $0,001^{c}$ \\
\hline Sikap & $68,0^{b} \pm 6,93$ & $75,0^{b} \pm 5,99$ & $0,001^{d}$ & $68,3^{a} \pm 4,09$ & $70,3^{a} \pm 4,75$ & $0,001^{c}$ \\
\hline Praktek & $67,0^{a} \pm 3,56$ & $71,6^{a} \pm 3,56$ & $0,001^{c}$ & $65,7^{a} \pm 5,10$ & $67,7^{a} \pm 4,69$ & $0,001^{c}$ \\
\hline
\end{tabular}

\section{Perilaku Kader Sebelum dan Sesudah Perlakuan pada Kedua Kelompok}

Tabel 2 menunjukkan bahwa sebelum dilakukan perlakuan (pelatihan dengan modul), rata-rata skor pengetahuan, sikap dan praktek antara kelompok perlakuan dan kelompok kontrol secara signifikan tidak berbeda ( $p$ value $>0,05$ ). Setelah dilakukan perlakuan terdapat perbadaan signifikan rata-rata pengetahuan, sikap dan praktek kader antara kelompok perlakuan dan kelompok kontrol $(p<0,05)$.

Tabel 3. manunjukkan hasil uji beda ratarata pengetahuan, sikap dan praktek pre dan post test pada masing-masing kelompok perlakuan dan kelompok kontrol. Hasil menunjukkan ada perbedaan rata-rata pengetahuan, sikap dan praktek pada pre-test dan post-test.

\section{Retensi Perilaku Kader Bulan Pertama dan Kedua pada Kelompok Perlakuan}

Tabel 4 menunjukkan rata-rata pengetahuan kader sesudah perlakuan 74,65 dengan standar deviasi 6,57, post-test bulan pertama didapatkan rata-rata pengetahuan kader adalah 87,59 dengan standar deviasi 4,88 . Sedangkan sikap post-test adalah 75,00 dengan standar deviasi 5,988, pengukuran post-test bulan pertama didapatkan median sikap kader adalah 82,50 dengan standar deviasi 5,33. Begitu juga untuk praktek kader rata-rata post-test adalah 71,60 dengan standar deviasi 3,56. Pengukuran post-test bulan pertama didapatkan rata-rata skor praktek kader adalah 82,68 dengan standar deviasi 5,07 . 
Tabel 4

Perbedaan Skor Pengetahuan, Sikap dan Praktek Bulan Pertama dan Bulan Kedua Sesudah Pelatihan pada Kelompok Perlakuan

\begin{tabular}{lccccc}
\hline \multicolumn{1}{c}{ Variabel } & $\begin{array}{c}\text { Sesudah } \\
\text { Perlakuan }\end{array}$ & $\begin{array}{c}\text { Bulan } \\
\text { Pertama }\end{array}$ & $p$ & $\begin{array}{c}\text { Bulan } \\
\text { Kedua }\end{array}$ & $p$ \\
\hline Skor Pengetahuan & $74,65^{\mathrm{a}} \pm 6,57$ & $87,59^{\mathrm{a}} \pm 4,88$ & $0,001^{\mathrm{c}}$ & $86,04^{\mathrm{a}} \pm 5,25$ & $0,067^{\mathrm{c}}$ \\
Skor Sikap & $75,00^{\mathrm{a}} \pm 5,98$ & $82,50^{\mathrm{b}} \pm 5,33$ & $0,001^{\mathrm{d}}$ & $82,50^{\mathrm{a}} \pm 4,52$ & $0,088^{\mathrm{d}}$ \\
Skor Praktek & $71,60^{\mathrm{a}} \pm 3,56$ & $82,68^{\mathrm{a}} \pm 5,07$ & $0,001^{\mathrm{c}}$ & $83,07^{\mathrm{a}} \pm 3,85$ & $0,705^{\mathrm{c}}$ \\
\hline \multicolumn{4}{c}{ Ket: $a=$ Rata-rata \pm Standar Deviasi } \\
$c=$ Paired t test
\end{tabular}

Hasil uji beda pengetahuan $(p=0,001)$, sikap $(p=0,01)$ dan praktek $(p=0,00)$ didapatkan nilai $p<0,05$, maka dapat disimpulkan ada perbedaan yang signifikan pengetahuan, sikap dan praktek antara post-test sesudah perlakuan dan post-test bulan pertama pada kelompok perlakuan. Pengukuran pengetahuan, sikap dan praktek kader bulan kedua yang merupakan kegiatan post-test 3, Hasil uji statistik dengan menggunakan uji beda menunjukkan rata-rata pengetahuan kader post-test bulan kedua adalah 86,04 dengan standar deviasi 5,25. Hasil post-test sikap bulan kedua adalah 82,50 dengan standar deviasi 4,52. Rata-rata praktek kader post-test bulan kedua adalah 83,07 dengan standar deviasi 3,85. Hasil uji statistik didapatkan nilai pengetahuan $(p=0,067)$, sikap $(p=0,088)$ dan praktek $(p=0,705)$ maka dapat disimpulkan untuk pengetahuan, sikap dan praktek tidak ada perbedaan yang signifikan.

\section{BAHASAN}

\section{Keterbatasan Penelitian}

Tidak adanya randomisasi dengan desain quasi eksperiment mengakibatkan pengelompokkan anggota sampel pada kelompok perlakuan dan kelompok kontrol tidak dapat sepenuhnya mengontrol variabel luar yang dapat mempengaruhi pelaksanaan perlakuan. Penelitian ini merupakan penelitian eksperimen semu, sehingga belum mampu sepenuhnya memastikan efektivitas intervensi yang diberikan terhadap perubahan pengetahuan, sikap dan praktek, namun dalam penelitian ini peneliti memastikan secara statistik melalui pengujian statistik. Peneliti kurang melakukan observasi dan wawancara secara mendalam dengan kader pendamping sehingga data yang diperoleh hanya berdasarkan data-data dari hasil kuesioner yang diberikan. Waktu evaluasi pengetahuan, sikap dan praktek baik pada kelompok perlakuan dan kelompok kontrol tidak sama, karena harus mengikuti jadwal Posyandu yang sudah di tentukan oleh Puskesmas. Waktu untuk pelatihan kurang sehingga untuk mengevaluasi keterampilan menjadi kurang efektif karena secara teori pelatihan untuk kader 25 jam pertemuan. Selain itu alat peraga yang digunakan untuk simulasi masih kurang.

\section{Karakteristik Responden}

Hasil uji satistik menunjukan tidak ada perbedaan yang bermakna pada karakteristik responden antara kelompok perlakuan dan kelompok kontrol, baik itu pendidikan, lama menjadi kader dan sumber informasi. Terdapat perbedaan umur kader antara kelompok perlakuan dengan kelompok kontrol, karena untuk mejadi seorang kader, umur tidak mempuyai syarat khusus. Syarat untuk menjadi kader posyandu adalah setiap warga yang bisa membaca dan menulis huruf latin, mempunyai waktu luang, memiliki kemampuan dan mau bekerja sukarela dengan ikhlas menjadi kader. ${ }^{7}$

\section{Perubahan Pengetahuan Kader}

Hasil penelitian menunjukan bahwa pengetahuan kader tidak berbeda sebelum perlakuan, baik pada kelompok perlakuan dan kelompok kontrol. Hal ini menunjukan bahwa karakteristik kader hampir sama. Pada saat pretest sebagian besar kader kurang mengetahui tentang kandungan ASI, cara mengatasi puting susu yang lecet, penyimpanan ASI, persiapan menyusui yang baik yang meliputi: menganjurkan ibu sebelum dan sesudah menyusui untuk mencuci tangan, menganjurkan ibu untuk minum 1 gelas air putih sebelum dan sesudah menyusui dan peranan kader menuju 
keberhasilan menyusui, keadaan ini merupakan kegiatan pendampingan atau penyuluhan yang berlangsung selama ini belum sepenuhnya memberdayakan kader atau melibatkan kader. Pada saat pre-test pengetahaun kader baru pada tahap tahu karena kader hanya mengingat kembali suatu materi yang telah dipelajari sebelumnya atau rangsangan yang telah diterima.

Uji beda pengetahuan yang dilakukan pada kedua kelompok meskipun terjadi perbedaan yang sangat bermakna, akan tetapi perubahan yang terjadi pada kelompok perlakuan jauh lebih besar dibandingkan pada kelompok kontrol. Hasil post-test menunjukan peningkatan pengetahuan kader mengenai kandungan ASI, manfaat ASI, pemberian ASI, penyimpanan ASI dan peranan kader menuju keberhasilan menyusui. Hal ini disebabkan pada kelompok perlakuan dilakukan pelatihan, modul dan metode ceramah serta tanya jawab. Menurut penelitian para ahli, indra yang paling banyak menyalurkan pengetahuan ke dalam otak adalah mata (kurang lebih $75 \%$ sampai $87 \%$ ), sedangkan $13 \%$ sampai $25 \%$ lainnya tersalur melalui indra yang lain. ${ }^{10}$ Hasil penelitian ini sejalan dengan penelitian terdahulu yang dilakukan Suharti yang menunjukkan adanya pengaruh pengetahuan dan keterampilan sebelum dan setelah dilakukan pelatihan teknik menyusui pada ibu nifas di RSD Raden Mattaher Jambi. ${ }^{11}$ Demikian pula dengan penelitian Sudarmanto, menyatakan bahwa adanya perbedaan yang bermakna pada pengetahuan, ketepatan kader dalam interpretasi hasil penimbangan setelah perlakuan dengan pelatihan menggunakan modul pendamping KMS ${ }^{8}$

Proses pelatihan merupakan informasi yang disampaikan kepada peserta berupa pengetahuan, skill dan pengalaman, serta menerangkan dan menjelaskan suatu ide, pengertian atau pesan secara lisan kepada kelompok sasaran yang memperoleh informasi dan pengetahuan yang diperoleh merupakan faktor yang sangat penting karena kader dapat menerapkan informasi yang diterima dalam upaya pemberian ASI eksklusif.7 Pelatihan yang dilakukan merupakan salah satu kegiatan yang penting agar kader mau dan mampu berperan serta dalam melaksanakan kegiatan posyandu atau program yang ada di puskesmas. Oleh karena itu pengetahuan dan keterampilan kader harus disesuaikan dengan tugas mereka dalam melaksanakan pendampingan atau penyuluhan. ${ }^{12}$

Pengetahuan kader dari post-test bulan pertama ke post-test bulan kedua terjadi penurunan, karena terlalu lama jarak pengukuran pengetahuannya dan intesitas kunjungan atau penyuluhan kurang. Kekuatan mengingat manusia makin lama makin berkurang yang pada akhirnya manusia akan mengalami kelupaan. Agar tidak mudah lupa maka pengetahuan kader yang didapat setelah pelatihan sebaiknya intesitas kunjungan kader pendampingan atau penyuluhan tetap dilaksanakan secara rutin dan berulang. ${ }^{9}$

Berbeda dengan pengetahuan kader yang tidak mendapat perlakuan, tidak menunjukan peningkatan, karena pengetahuan kader berdasarkan dari pengalaman dan media massa, bukan berasal dari tenaga kesehatan atau fasilitator langsung, sehingga kurang mampu menggali sejauh mana pengetahuan kader. Dimana rata-rata umur dan masa kerja kader pada kelompok ini lebih tinggi dari pada kelompok perlakuan. Umur yang lebih tua memungkinkan kemampuan untuk mengingat lebih rendah, selain itu keinginan untuk mencari tahu hal baru juga lebih rendah dan pengalaman yang lebih dirasakan adalah yang bermanfaat bagi diri mereka.

\section{Perubahan Sikap Kader}

Sikap adalah reaksi atau respon seseorang yang masih tertutup terhadap stimulus atau objek dan merupakan kesiapan atau kesediaan untuk bertindak. Sikap kader yang dimaksudkan dalam penelitian ini adalah perasaan kader terhadap pernyataan mengenai ASI eksklusif dalam bentuk penyuluhan atau pendampingan. ${ }^{13}$

Hasil pre-test pada kedua kelompok menunjukan sikap yang sama pada awal penelitian. Pengaruh modul dalam upaya perbaikan sikap kader dalam pemberian ASI eksklusif sebelum dan setelah perlakuan pada masing-masing kelompok menunjukan perbedaan yang bermakna. Dari pre-test dan post-test dapat dilihat adanya peningkatan rerata sikap kader dalam upaya pemberian ASI eksklusif pada kedua kelompok. Hasil ini sejalan dengan penelitian yang dilakukan di kecamatan Darmaga dan Ciomas Kabupaten Bogor, menjelaskan bawah diberinya intervensi 
pendidikan gizi bagi ibu balita dan kader posyandu terjadi peningkatan sikap, rerata sikap gizi kader lebih tinggi pada kelompok intervensi dibandingkan, kelompok kontrol. ${ }^{14}$ Salah satu hasil atau dampak positif dari proses belajar adalah terjadi perubahan ranah afektif yakni terciptanya kesadaran dan adanya peningkatan sikap positif terhadap apa yang diajarkan. Kaitan dengan penelitian ini adalah bahwa pelatihan yang diberi modul kepada kader dalam upaya pemberian ASI eksklusif dapat meningkatkan kesadaran dan menghasilkan perubahan sikap positif kearah yang lebih baik. ${ }^{15}$

Rerata umur pada kelompok perlakuan lebih rendah jika dibandingkan dengan kelompok kontrol. Umur yang relatif rendah, cenderung membuat kelompok perlakuan lebih mudah menerima informasi, termasuk informasi yang berkaitan dengan ASI eksklusif. Umur muda, lebih mudah untuk diberikan masukan tentang hal-hal yang baru. Sedangkan kelompok kontrol masa kerja relatif lebih lama dan tidak diberi perlakuan sama sekali sehingga ada kecenderungan menganggap penyuluhan atau pendampingan mengenai ASI eksklusif bukan hal yang sangat penting karena mereka telah menjadi kader sudah cukup lama tanpa melakukan pendampingan atau penyuluhan tidak menimbulkan masalah. Hal ini dapat menjadi salah satu peyebab rerata sikap kader pada kelompok perlakuan lebih tinggi pada kelompok kontrol. ${ }^{14}$

Perubahan sikap kader dalam upaya pemberian ASI eksklusif pada kelompok perlakuan bulan pertama terjadi peningkatan, namun post-test bulan kedua tidak terjadi peningkatan nilai sikap kader. Sesuai dengan teori bahwa pengetahuan adalah stimulus bagi perubahan sikap. Menurut WHO sikap menggambarkan suka atau tidak suka seseorang terhadap suatu tindakan dan sikap sering diperoleh dari pengalaman sendiri atau dari orang lain, seseorang yang mempunyai sikap positif tidak selalu terwujud dalam suatu tindakan nyata. ${ }^{16}$

\section{Perubahan Praktek Kader}

Praktek atau keterampilan adalah suatu kemampuan dalam melaksanakan tugas atau pekerjaan dengan menggunakan anggota badan dan peralatan yang tersedia, serta mampu memotivasi dan bekerjasama dengan orang lain. Praktek kader yang dimaksudkan dalam penelitian ini adalah kemampuan seseorang kader dalam menjelaskan dan mengajarkan persiapan pemberian ASI, cara pemberian ASI, cara memerah ASI dan cara penyimpanan ASI. ${ }^{17}$

Praktek kader sebelum perlakuan dalam upaya pemberian ASI eksklusif menunjukan tidak ada perbedaan antara kedua kelompok. Setelah dilakukan pelatihan dengan pedoman observasi terhadap praktek atau keterampilan kader, terdapat perubahan nilai rata-rata praktek kader meningkat dibandingkan kelompok kontrol. Perbedaan ini disebabkan karena metode yang digunakan dalam pelatihan ini adalah simulasi (praktek) sedangkan pada kelompok kontrol tidak diberi perlakuan. Dengan dilakukannya simulasi atau praktek langsung akan lebih mempermudah cara penyampaian informasi yang dapat meningkatkan pengetahuan dan praktek kader. ${ }^{16} \mathrm{Hal}$ ini sejalan dengan penelitian Sutoro bahwa pembelajaran menggunakan metode simulasi pidato bisa meningkatkan keterampilan siswa. ${ }^{18}$ Begitu juga survei yang dilakukan Edy di Kecamatan Tempua tentang pelatihan kader dengan metode belajar berdasarkan masalah, terjadi peningkatan skor keterampilan sebesar 4,6 persen setelah evaluasi 2 minggu. ${ }^{19}$

Peningkatan memang tidak begitu berbeda pada kedua kelompok, hal ini disebabkan pengalaman dari semua responden adalah sama. Dalam kegiatan pelatihan ini hanya memberikan penguatan terhadap apa yang sudah dimiliki para kader, terkait dengan materi ASI, sebenarnya bukan materi yang baru karena sudah banyak media massa yang mengulas materi ASI. Meskipun sudah banyak media massa yang menayangkan tentang segala sesuatu yang terkait dengan ASI eksklusif, tetapi kadang-kadang kader atau masyarakat masih membutuhkan penguat dari orang-orang yang ada di sekitarnya untuk merubah perilaku kelompok kontrol yang menunjukkan tidak ada perbedaan praktek kader dalam upaya pemberian ASI eksklusif, hal ini disebabkan karena kader tidak medapat pelatihan. Pengetahuannya tentang ASI hanya didapat dari membaca dan mendengar dari orang lain. Kader lebih banyak belajar dari pengalamannya dalam praktek pemberian ASI. $\mathrm{Hal}$ ini sesuai dengan pernyataan Azwar menyatakan bahwa orang lain merupakan salah 
satu diantara komponen sosial yang ikut mempengaruhui sikap atau perilaku. ${ }^{13}$

\section{Efektivitas Modul dalam Perubahan Perilaku Kader}

Hasil penelitian membuktikan pelatihan menggunakan modul efektif untuk meningkatkan skor pengetahuan. Hasil penelitian ini sejalan dengan penelitian di Kecamatan Mangarabombang Kabupaten Takalar Sulawesi Selatan terjadi peningkatan pengetahuan gizi ibu sebesar 25,5 poin setelah pendampingan. ${ }^{20}$ Keadaan ini memberikan gambaran bahwa pelatihan dengan menggunakan modul sangat bermanfaat bagi peningkatan pengetahuan, meskipun masa evaluasi terhadap pengetahuan ada yang dilakukan satu bulan setelah pelatihan dan dua bulan setelah pelatihan. Karena modul merupakan bahan ajar cetak yang dirancang untuk dapat dipelajari secara mandiri oleh peserta pembelajaran. Modul disebut juga media untuk belajar mandiri karena di dalamnya telah dilengkapi petunjuk untuk belajar sendiri. Pembelajaran yang memberi kesempatan kepada pembelajar untuk meniru satu kegiatan yang dituntut dalam pekerjaan sehari- hari atau yang berkaitan dengan tanggung jawabnya. Sehingga ketika dilakukan evaluasi pengetahuan kembali terjadi peningkatan. ${ }^{21}$

Hasil analisis sikap setelah pelatihan dengan media modul ASI eksklusif menunjukkan perbedaan antara kedua kelompok dengan $p<0,05$ sedangkan pada post-test bulan pertama tidak terdapat perbedaan sikap yang bermakna. Rata-rata sikap pada kelompok perlakuan lebih tinggi jika dibandingkan dengan kelompok kontrol. Rerata sikap yang lebih tinggi pada kelompok perlakuan diperkirakan karena dalam pelatihan dilakukan ceramah, simulasi dan intraksi individu secara langsung, sedangkan kelompok kontrol tidak diberi perlakuan sama sekali sehingga sikap kader tidak terjadi perubahan hal ini bisa saja di sebabkan pengalaman kader.

Sikap yang diperoleh lewat pengalaman akan menimbulkan pengaruh langsung terhadap perilaku berikutnya, pengaruh tersebut lebih berupa predisposisi perilaku yang akan direalisasikan apabila kondisi dan situasi memungkinkan. kondisi tersebut sangat berpengaruh terhadap sikap dengan pernyataan dan antara pernyataan sikap dengan perilaku. ${ }^{13}$

Hasil analisa statistik terhadap nilai praktek menunjukkan bahwa pada kelompok perlakuan dan kelompok kontrol mengalami kenaikan secara bermakna. Hasil pengukuran terhadap rerata kenaikan nilai praktek menunjukkan bahwa nilai kelompok perlakuan lebih tinggi dibandingkan nilai kelompok kontrol. Pada kelompok perlakuan menggunakan metode simulasi yang mana metode ini dapat mengatasi permasalahan yang dihadapi dan dapat meningkatkan akselerasi pemikiran dan perasaan sikap dan psikomotorik pembelajaran. ${ }^{16}$ Kelompok kontrol tidak dilakukan kegiatan sama sekali, pada kelompok ini kurang menguntungkan karena kader tidak memungkinkan untuk berkomunikasi dan menanyakan hal-hal yang kurang dipahaminya. Metode belajar yang lebih banyak memberikan keuntungan adalah metode belajar dengan komunikasi dua arah antara pengajar dan peserta latih, dengan demikian peserta dapat dengan lebih mudah memahami materi yang diberikan. ${ }^{22}$

Hasil ini sejalan dengan penelitian terdahulu, menunjukkan ada perbedaan keterampilan kader dalam pengukuran antropometri sebelum dan sesudah pelatihan. Peningkatan rerata skor pengetahuan,sikap dan praktek lebih tinggi pada kelompok perlakuan, karena pada kelompok tersebut lebih banyak indra yang digunakan, yaitu penglihatan pendengaran dan peraba. Semakin banyak indra yang digunakan untuk menerima sesuatu maka semakin banyak dan semakin jelas pengetahuan yang diperoleh. ${ }^{23}$ Begitu juga dengan hasil penelitian Inong dengan pelatihan terjadi peningkatan pengetahuan kader tentang program KADARZI, kelancaran kegiatan program KADARZI sangat erat kaitannya dengan keaktifan kader pendamping sebagai pelaksanaannya di masyarakat. ${ }^{24}$ Salah satu upaya pendukung untuk memperdayakan masyarakat terutama kader agar dapat memelihara, meningkatkan dan melindungi kesehatan berkaitan dengan pengetahuan, sikap dan praktek/keterampilan yang diaplikasikan dalam bentuk tindakan/praktek akan berpengaruh terhadap adopsi prilaku yang sifatnya baru dalam kehidupannya. ${ }^{16}$ 


\section{SIMPULAN DAN SARAN}

\section{Simpulan}

Hasil penelitian menunjukan terjadi peningkatan skor pengetahuan, sikap dan praktek kader pada kelompok perlakuan setelah diberi intervensi, sedangkan untuk kelompok kontrol tidak terjadi peningkatan pengetahuan, sikap dan praktek kader. Rata-rata perbedaan pencapaian kenaikan skor pada kelompok perlakuan nilai pengetahuan 9,63 , sikap 6,35 dan praktek 4,55 sedangkan kelompok kontrol rata-rata hanya terjadi peningkatan pengetahuan 3,27, sikap 2,03 dan praktek 2,00.

\section{Saran}

Pendampingan kader dapat dikembangkan sebagai salah satu model intervensi berkelanjutan yang efektif agar program yang ada di Dinas Kesehatan Kota Bengkulu dan Puskesmas dapat tercapai, perlunya pelatihan kader pendamping atau kader posyandu kepada seluruh kader agar dapat menambah pengetahuan dan keterampilan kader. Sebaiknya evaluasi dilakukan lebih dari satu kali dalam sebulan atau satu bulan yaitu 2 atau 3 bulan sehingga retensi pengetahuan, sikap dan praktek kader benar-benar terukur sebagai hasil pendampingan. Petugas kesehatan hendaknya mampu memberdayakan kader dan tidak mengambil alih tugas kader di posyandu, akan tetapi hanya mengamati kegiatan kader sebagai acuan untuk bimbingan dan pembinaan supaya kader bisa mandiri dan terampil dalam memberikan pelayanan kepada masyarakat.

\section{RUJUKAN}

1. Pudjiadi S. Ilmu Gizi Klinis Pada Anak. Jakarta: FKUI, 2005.

2. Departemen Kesehatan RI. Pedoman Umum Pemberian Makanan MP-ASI Lokal. Jakarta; Direktorat Gizi, 2005.

3. Kementrian Kesehatan RI. Makalah pada Pekan ASI Sedunia 2010. Jakarta 22 September.

4. Kementerian Kesehatan RI. Laporan RISKESDAS 2010. Jakarta: Badan Litbang Kesehatan, 2010.
5. Dinas Kesehatan Bengkulu. Propil Dinas Kesehatan 2011. Bengkulu: Dinas Kesehatan Bengkulu, 2011.

6. Astika. Kesehatan Ibu Dan Anak Dalam Mellenium Development Goals (MDGS). Jakarta: Nuha Medika, 2012.

7. Departemen Kesehatan RI. Panduan Pelatihan Kader Posyandu. Jakarta: Direktorat Gizi, 2005.

8. Sudarmanta. Pengaruh Pelatihan dengan Modul Pendampingan KMS Terhadap Pengetahuan dan Ketepatan dalam Interprestasi Hasil Penimbangan di Posyandu. Thesis. Yogyakarta: Universitas Gajah Mada, 2010.

9. Ferry. Pengaruh Pendampingan Bidan Terhadap Keberhasilan Pemberian ASI Eksklusif Di Kota Pasuruan. Skripsi. Semarang: Universitas Diponegoro, 2011.

10. Notoadmodjo S. Pendidikan Dan Perilaku Kesehatan. Jakarta: Rineke Cipta, 2003.

11. Suharti, Pengaruh Penyuluhan dan Pelatihan Teknik Menyusui Terhadap Pengetahuan dan Keterampilan lbu Nifas di RSD Raden Mattaher Jambi, Jurnal Poltekkes Jambi 2008; 5(Desember): 23-39

12. Departemen Kesehatan RI. Pedoman Pengelolaan Pembinaan Pelatihan Kader Posyandu UPGK. Jakarta: Direktorat Gizi, 1992.

13. Azwar S. Sikap Manusia Teori dan Pengukurannya. Yogyakarta: Pustaka Pelajar; 2012

14. Nikmawati EE, Kusharto CM, Khosan A, Sukandar D, Atmawikarta, A. Intervensi Pendidikan Gizi Bagi lbu Balita dan Kader Posyandu untuk Meningkatkan Pengetahuan, Sikap dan Keterampilan Serta Status Gizi Balita. Jurnal Pendidikan Teknologi Kejuruan 2009;5(15): 407-417.

15. Syah, 2002.Psikologi Pendidikan Dengan Pendekatan Baru. Bandung: Remaja Rosdakarya;

16. Notoadmodjo S. Ilmu Perilaku Kesehatan. Jakarta : Rineka Cipta, 2010.

17. Jennifer Stewart-Glenn, 2008. MSN, FNPBC . Knowledge, Perceptions, And Attitudes Of Managers, Coworkers, And Employed Breastfeeding Mothers. AAOHN Journal.2008;56(10): 423-429

18. Sutorom. Peningkatan Keterampilan Pidato Persuasif pada Pembelajaran Bahasa Indonesia Melalui Metode Simulasi Lomba 
Pidato Berbahasa Indonesia Pada Kelas XII IPS 1 Semester 1 SMA Negeri Ajibarang Tahun Pembelajaran 2009/2010. Jurnal DIDAKTIKA 2009; 4(2): 16-26

19. Edy, Laksmi. Pengaruh pelatihan Dengan Metode Belajar Berdasarkan Masalah (BBM) dalam Kegiatan Kader Posyandu; Studi di Kecamatan Tempuran Kabupaten Magelang. Media Medika Indonesia. 2009;42(3):16-26

20. Ayu SA. Pengaruh program Pendampingan Gizi Terhadap Pola Asuh, Kejadian Infeksi dan Status Gizi Balita Kurang energi Protein. Media Gizi Pangan.2009;8(2):1424

21. Departemen Kesehatan RI. Pedoman Penyusunan Kurikulum dan Modul
Pelatihan Berorientasi Pembelajaran. Jakarta: Pusdiklat Kesehatan, 2003.

22. Liliweri Alo, 2011. Dasar-Dasar Komunikasi Kesehatan, Yogyakarta:Pustaka Pelajar;

23. Fitri MH, Mardiana. 2011, Keterampilan Kader Posyandu Sebelum dan Sesudah Pelatihan. Jurnal Kesehatan Masyarakat. 2011; 7(1):25-31

24. Gunanti IR, Devi SR,Adriani M Pemberdayaan Kader Posyandu Melalui Penerapan Metode Konseling Gizi Dalam Upaya Meningkatkan Kualitas Pembinaan Program Keluarga Sadar Gizi (KADARZI). Buletin Penelitian Sistem Kesehatan 2005;8(1):12-22. 